\title{
The scuttle fly (Diptera: Phoridae) assemblages of pine plantations of the Biała Forest (Poland)
}

\author{
Ewa Durska
}

\begin{abstract}
Durska, E. 2009: The scuttle fly (Diptera: Phoridae) assemblages of pine plantations of the Biała Forest (Poland). — Entomol. Fennica 20: 170-178.

Scuttle fly diversity in disturbed habitats was evaluated on plots in pine plantations of Poland's Biała Forest. The assemblages present in the two years were assessed for the abundance of species, dominance structure, similarity and species richness, as well as in regard to indices of species diversity, evenness and fidelity. Megaselia brevicostalis was the first dominant on each of the three plots and in both study years. The number of species and their abundance was greatest on the turn of August and September. Most of the dominants and characteristic species are multivoltine, showing spring and late summer/autumn activity.
\end{abstract}

E. Durska, Department of Ecology and Biodiversity, Museum and Institute of Zoology, PAS, Wilcza 64,00-679 Warsaw, Poland; Email: edurska@miiz.waw.pl

Received: 2 April 2008, accepted 5 June 2008

\section{Introduction}

Phoridae (scuttle flies) constitute one of the most abundant and diverse families of Diptera of woodlands, meadows, agroecosystems and urban habitats. To date, over 3200 species have been described, a quarter of these from the Palaearctic Region (Disney 1991).

As recent studies make clear, assemblages of scuttle flies not only offer an effective representation of biodiversity, but also serve in investigations of habitat recolonisation (Disney 1994; Durska 2001a, 2002, 2003, 2006, Prescher et al. 2002; Disney \& Durska 2008).

In my previous studies, I found that the scuttle fly assemblage in pine plantations greatly differed in its species composition from the assemblages in the older age-classes of the succession series of moist pine forest in the Białowieża Primeval Forest. I observed a complete exchange of dominant species even in young-growth (Durska 2001a).

The scuttle fly assemblages also react very strongly to habitat pollution. An increase in pollution brings about significant changes in the proportion of trophic groups and the number of species with zoophagous larvae decreases while that of saprophagous increases (Durska 1996).

During my studies in the Białowieża Primeval Forest I also stated that scuttle fly assemblages might be regarded not only as highly indicatory because of their sensitivity to habitat changes but also of possessing specific groups of characteristic species in all four age-classes (pine plantation, young-growth stand, timber stand and oldgrowth stand) (Durska 2001a).

It is known that "a complex ecosystem offers more options than a simpler one when placed under stress" (Moore 2005), and habitat heterogeneity due to such disturbances as cutting, grazing, wildfires or windthrow may create very similar conditions for patch-assemblages of insects as within a patch surrounded by older-phase stands (Tscharntke \& Brandl 2004). Indeed, disturbance may be one of the factors controlling species diversity (Östman et al. 2006; Tanner \& Belling- 
ham 2006). There is little information on how disturbances affect the diversity of Phoridae in the earliest phase of succession. Only my investigations (Durska 2001a, 2006) in the pine plantations in the Białowieża Primeval Forest and the Tuchola Forest, and those by Prescher et al. (2002) in the chestnut belt of the Alps after wildfires, provides comparable data.

The aim of my work was thus to determine the structure of the assemblages of scuttle flies found on small plots in pine plantations established following clear-cutting in the moist pine forest habitats of Biała Forest in Poland, as well as to document the attendant phenology.

In this paper, I examine the abundance of species, dominance structure, similarity and species richness, as well as species diversity, evenness and habitat fidelity (considering the level of similarity of assemblages in stands in the old-growth phase).

\section{Materials and methods}

\subsection{Study area and sampling}

This study formed a part of a wider research on the secondary succession of scuttle fly assemblages in moist pine forest habitat, and was carried out in Biała Forest in Poland (52 $30^{\prime}-53^{\circ} 00^{\prime}$ $\mathrm{N}, 20^{\circ} 40^{\prime}-21^{\circ} 30^{\prime} \mathrm{E}$ ) in 1986 and 1987 . This is a large forest complex (over 64,000 ha) on the Polish Lowland with a preponderance of managed tree stands. Plant communities of moist pine forest habitat are represented there by the association Peucedano-Pinetum Mat., in its Sarmatian variant (Matuszkiewicz et al. 1993).

According to phytosociological analyses in the area there are slight differences in floristic composition between old-growth and clearings with young tree seedlings (Matuszkiewicz et al. 1993). Under natural conditions, Scots pine is eliminated by Norway spruce, which shades the understorey severely. Clear cutting is therefore employed commonly to facilitate the regeneration of pine from seed.

Three plots (ca. 5 ha) were randomly selected within even-aged pine plantations. The plots (coded $62 g, 34 f$ and $32 n$ ) had either two-year-old pines $(34 f)$ or three-year-old pines $(62 g$ and $32 n)$ in 1986. Distances between the plots did not exceed $5 \mathrm{~km}$.

Scuttle flies were collected using yellow plastic pans, $18 \mathrm{~cm}$ in diameter, containing water solution of $75 \%$ ethylene glycol for conservation of the insects and some detergent (Bańkowska \& Garbarczyk 1982). Flies were thus sampled using five such traps installed (dispersed) on the ground on each plot. Trapping continued from April through to October, with traps emptied fortnightly.

The use of the yellow plastic pans provides for the collection of material from both the canopy and forest floor (Durska 1996, 2001a). Disney (2004) reported yellow-trap selectivity for particular scuttle fly species while it is known that colour (from red via orange to yellow) can manipulate "the direction of flies' movements and assists the prolongation of the search for food" (Lunau et al.2005). Overall, studies using yellow pans by myself and others, confirm that ca. $70 \%$ of all Phoridae caught are flies of the genus Megaselia (Disney 1994, Durska 1996, 2001a, 2006). In turn, studies by Goos (1975) on flying insects in sugar-beet plantations combine with my own investigations (Durska 1996, 2001a, 2006) to confirm the status of the Phoridae among the families of Diptera caught most abundantly in yellow pans.

\subsection{Statistical analyses}

I confined my analysis of scuttle fly assemblages to the male individuals of all genus present, as most Megaselia females are not identifiable to species level at our present state of knowledge and so have only been identified to genus level.

In describing the assemblages, I took account of the relative abundance of males of different species, as well as the dominance structures, performing calculations for each plot and each study year. In terms of the male individuals, "Dominant" species were those with a relative abundance $\geq 1 \%$.

I calculated the Shannon-Weaver diversity index $\left(H^{\prime}\right)$ using the data from each plot, in accordance with the formula:

$H^{\prime}=-\Sigma p i \log _{\mathrm{e}} p i$ 
where $p i=N i / N ; N i$ is the number of individuals of the i-th species and $N$ the total number of individuals. The diversity index $\left(H^{\prime}\right)$ was calcutated for each study year and the differences between the years were tested using $\chi_{\text {L }}$-test (Magurran 1988). mula:

My analysis for evenness involved the for-

$J^{\prime}=H^{\prime} / \log _{\mathrm{e}} s$

where $s$ is the species richness (species number).

I also applied Spearman rank correlation coefficients $(r)$ in comparing the scuttle fly assemblages from the two years. I made further between-year comparisons of the assemblages using two similarity indices: Sørensen's quotient $(S \varnothing)$ (Sørensen 1948) and Morisita's quotient (Mo) as modified by Horn (1966). The former is based on presences and absences of species:

$S ø=2 a / b+c$

where: $a$ is the number of common species, $b$ is the number of species of the first assemblage (1986) and $c$ is the number of species of the second assemblage (1987). I used Mo to calculate the similarity of dominance structures in respect to all species or dominants (abundance $\geq 1 \%$ ) in the pine plantation assemblages obtained in the two years. The formula is:

Mo $=\frac{2 \sum_{i=1}^{s} x_{i} y_{i}}{\sum_{a=1}^{s} x_{a}{ }^{2}+\sum_{a=1}^{2} y_{a}{ }^{2}}$

where: $x_{i}, y_{i}$ are the percentages of common species, $x_{a}, y_{a}$ are the percentages of particular species in each of the assemblages compared (1986 and 1987) and $s$ is the total number of species. Mo presents the similarity of dominance structures of high-abundance species very well. This formula is appropriate where the data are expressed as the proportions of common species $\left(x_{i}, y_{i}\right)$ of the respective samples composed of species $i$ (Horn 1966).

I used habitat fidelity $(F)$, expressed quantitatively, to determine those species that were characteristic of pine plantations, employing the formula:
$F=a / b \times 100$

where $a=$ the number of individuals of a given species in a given habitat, and $b=$ the total number of individuals of a given species in all compared habitats. To assess the habitat fidelity of assemblages to the study area, I compared the scuttle fly assemblages of pine plantations (three plots) with those of Biala Forest stands in the oldgrowth phase (also three plots, previous data; Durska 1996), five yellow pans being hung up on the crowns of trees on each, during the same two study seasons (1986 and 1987, simultaneous trapping period in pine plantations and old-growth stands). I trapped from April through to October, emptying traps fortnightly at the same time in the two habitats compared (pine plantations and oldgrowth stands in 1986 and 1987) (Durska 1996).

I also compared the seasonal and inter-annual changes in the abundance (number of individuals) and species richness (number of species) of the scuttle fly assemblages from 1986 and 1987.

\section{Results}

I collected a total of 6155 adult individuals of phorid flies (3506 in 1986 and 2649 in 1987), attributing these to 52 scuttle fly species (42 in 1986 and 44 in 1987), and thus obtaining almost 50\% of the Phoridae known from pine plantations on the Polish Lowland (Disney 1991, Durska 2001a, b, Durska 2006). (Tables 1-2). The number of recorded species varied from 23 to 31 in the study plots.

\subsection{Assemblage structure}

In both years, individuals of species in the genus Megaselia accounted for over $90 \%$ of the phorid assemblage associated with each plot. I confined my considerations to males identified to species level (i.e. 2911 individuals), these constituting ca. $50 \%$ of all specimens collected (Table 1).

I obtained very high values for the indices of qualitative similarity $(S \varnothing)$ and quantitative similarity $(\mathrm{Mo})$ calculated for common dominants in the two seasons (Table 3 ).

The fact that 31 of the 52 species occurred in 
Table 1. List of scuttle fly (Phoridae) species with numbers of individuals $(N)$ and relative abundances $(\% N)$ given for the individual years. *: Dominant species with dominance $\geq 1 \%$ during one or both years.

\begin{tabular}{|c|c|c|c|c|}
\hline \multirow[b]{2}{*}{ Species } & \multicolumn{2}{|c|}{1986} & \multicolumn{2}{|c|}{1987} \\
\hline & $N$ & $\% N$ & $N$ & $\% N$ \\
\hline Anevrina thoracica (Becker, 1901 & - & - & 1 & 0.04 \\
\hline Anevrina unispinosa (Zetterstedt, 1860) & 1 & 0.03 & - & - \\
\hline "Borophaga subsultans (Linnaeus, 1767) & 10 & 0.29 & - & - \\
\hline Conicera floricola Schmitz, 1938 & - & - & 1 & 0.04 \\
\hline${ }^{*}$ Conicera similis (Haliday, 1833 ) & 122 & 3.48 & 33 & 1.25 \\
\hline *Diplonevra funebris (Meigen, 1830) & 25 & 0.72 & 13 & 0.49 \\
\hline Gymnophora nigripennis Schmitz, 1926 & 1 & 0.03 & 1 & 0.04 \\
\hline Gymnophora sp. & 4 & 0.11 & 1 & 0.04 \\
\hline Megaselia affinis (Wood, 1909) & 2 & 0.06 & - & - \\
\hline${ }^{*}$ Megaselia altifrons (Wood,1909) & 18 & 0.51 & 20 & 0.76 \\
\hline Megaselia basispinata (Lundbeck, 1920) & - & - & 1 & 0.04 \\
\hline${ }^{*}$ Megaselia brevicostalis (Wood, 1910) & 515 & 14.69 & 452 & 17.06 \\
\hline Megaselia campestris (Wood, 1908) & 2 & 0.06 & - & - \\
\hline Megaselia dahli (Becker,1901) & 3 & 0.09 & 1 & 0.04 \\
\hline *Megaselia diversa (Wood, 1909) & 9 & 0.26 & 1 & 0.04 \\
\hline *Megaselia giraudii-complex (Egger, 1862) & 21 & 0.60 & 48 & 1.81 \\
\hline Megaselia groenlandica (Lundbeck,1901) & 1 & 0.03 & - & - \\
\hline Megaselia gregaria (Wood, 19100) & - & - & 1 & 0.04 \\
\hline Megaselia henrydisneyi Durska, 1998 & - & - & 1 & 0.04 \\
\hline *Megaselia hyalipennis (Wood, 1912) & 13 & 0.37 & 2 & 0.08 \\
\hline "Megaselia involuta (Wood, 1910) & 9 & 0.26 & 10 & 0.38 \\
\hline Megaselia lata (Wood, 1910) & - & - & 1 & 0.04 \\
\hline Megaselia latifrons (Wood, 1910) & 3 & 0.09 & 3 & 0.11 \\
\hline Megaselia longicostalis (Wood, 1912) & 2 & 0.06 & 2 & 0.08 \\
\hline Megaselia mallochi (Wood, 1909) & - & - & $1 \overline{3}$ & 0.49 \\
\hline "Megaselia manicata (Wood, 1910) & 24 & 0.68 & 60 & 2.27 \\
\hline Megaselia meconicera (Speiser, 1925) & 1 & 0.03 & 1 & 0.04 \\
\hline *Megaselia minor (Zetterstedt, 1848) & 34 & 0.97 & 30 & 1.13 \\
\hline${ }^{*}$ Megaselia nigriceps (Loew, 1866) & 64 & 1.83 & 44 & 1.66 \\
\hline *Megaselia pleuralis (Wood, 1909) & 61 & 1.74 & 33 & 1.25 \\
\hline Megaselia plurispinulosa (Zetterstedt, 1860) & 1 & 0.03 & 4 & 0.15 \\
\hline Megaselia posticata (Strobl, 1898) & 1 & 0.03 & - & - \\
\hline Megaselia propinqua (Wood, 1909) & - & - & 5 & 0.15 \\
\hline${ }^{*}$ Megaselia pulicaria-complex (Fallén, 1823) & 123 & 3.51 & 112 & 4.23 \\
\hline${ }^{*}$ Megaselia pumila (Meigen, 1830) & 24 & 0.68 & 26 & 0.98 \\
\hline Megaselia pusilla (Meigen, 1830) & 4 & 0.11 & 1 & 0.04 \\
\hline "Megaselia scutellaris (Wood, 1909) & 68 & 1.94 & 200 & 7.55 \\
\hline Megaselia spinigera (Wood, 1908) & 1 & 0.03 & - & - \\
\hline Megaselia stigmatica (Schmitz, 1920) & 1 & 0.03 & - & - \\
\hline *Megaselia subnudipennis (Schmitz, 1919) & 14 & 0.04 & - & - \\
\hline *Megaselia unicolor (Schmitz, 1919) & 31 & 0.88 & 1 & 0.04 \\
\hline${ }^{*}$ Megaselia verralli (Wood, 1910) & 233 & 6.65 & 42 & 1.59 \\
\hline Megaselia woodi (Lundbeck, 1922) & 6 & 0.17 & 1 & 0.04 \\
\hline${ }^{*}$ Megaselia xanthozona (Strobl, 1892) & 53 & 1.51 & 31 & 0.79 \\
\hline Megaselia zonata (Zetterstedt, 1838)' & - & - & 2 & 0.08 \\
\hline Metopina heselhausi Schmitz, 1914 & 1 & 0.03 & 5 & 0.19 \\
\hline${ }^{*}$ Metopina oligoneura (Mik, 1867) & 72 & 2.05 & 126 & 4.76 \\
\hline Phalacrotophora sp. $n$ & - & - & 1 & 0.04 \\
\hline Triphleba bifida Schmitz, 1949 & - & - & 2 & 0.08 \\
\hline Triphleba distinguenda (Strobl, 1892) & - & - & 1 & 0.04 \\
\hline Triphleba minuta (Fabricius, 1787) & _ & - & 1 & 0.04 \\
\hline Triphleba opaca (Meigen, 1830) & 1 & 0.03 & 1 & 0.04 \\
\hline Triphleba subcompleta Schmitz, 1927 & 1 & 0.03 & 1 & 0.04 \\
\hline${ }^{*}$ Triphleba trinervis (Becker, 1901) & 11 & 0.31 & - & - \\
\hline Triphleba sp. & 1 & 0.03 & - & - \\
\hline Megaselia sp. females & 1,841 & 52.51 & 1,238 & 46.73 \\
\hline Megaselia sp. males & 73 & 2.08 & 78 & 2.94 \\
\hline Megaselia sp. A & - & - & 5 & 0.19 \\
\hline Total & 3,506 & 100 & 2,649 & 100 \\
\hline
\end{tabular}


Table 2. Scuttle fly overall species richness, diversity and evenness as well as their means and standard deviations calculated from the values of the three study plots in pine plantations in 1986 and 1987.

\begin{tabular}{lll}
\hline Variable & 1986 & 1987 \\
\hline Spiecies richness $(s)$ & 42 & 44 \\
$\quad$ Mean & 27.7 & 26.7 \\
$\quad$ Standard deviation & 1.53 & 4.04 \\
Diversity $\left(H^{\prime}\right)$ & 3.59 & 3.44 \\
$\quad$ Mean & 3.36 & 3.32 \\
Standard deviation & 0.243 & 0.429 \\
Evenness $\left(J^{\prime}\right)$ & 0.96 & 0.91 \\
Mean & 1.01 & 1.01 \\
Standard deviation & 0.063 & 0.112 \\
\hline
\end{tabular}

both years resulted in a Sørensen quotient of similarity equal to 0.72 (Table 3 ). Eight out of twenty two dominant species were present in both years with dominances $\geq 1 \%$ (Table 1). On each plot and in both study seasons, the dominants made up over $80-90 \%$ of each assemblage (of males) (Fig. 1).

The scuttle fly assemblages obtained from the three plots representing Biała Forest pine plantations had the polysaprophagous Megaselia brevicostalis as their first dominant in both study seasons, accounting for $26-39 \%$ of all individuals. Megaselia verralli, a pyrophilous species of unknown biology was another dominant, accounting for up to $16 \%$ of the assemblages on all plots except $62 g$ in 1987, from which I only obtained two individuals (Fig. 1).

I found close to identical species richness $(s)$ for the scuttle fly assemblages of the two years (Table 2) with their overall species richness (determined number of species) of $s=52$.

The assemblages of scuttle flies characterised for each year were associated with rather high values for the indices of species diversity $\left(H^{\prime}=\right.$ 3.64) and evenness $\left(J^{\prime}=0.92\right)$, though the latter was more marked in 1986 than in 1987 (Table 2, $p<0.0001)$. While I obtained a very high value for the Spearman's correlation between the assemblages of the two study years $\left(r_{s}=0.8947\right)$, the assemblages from the Biała Forest pine plantations had little in common with those of its old-growth stands in the same two study seasons $\left(r_{s}=0.1044\right)$ (Durska 1996).

The ten species displaying the highest (89-
Table 3. Between-year similarity of scuttle fly assemblages in pine plantations in 1986-1987. Sø: Sørensen quotient, Mo: Morisita quotient.

\begin{tabular}{lcc}
\hline & Sø & Mo \\
\hline All species & 0.72 & 0.92 \\
Common dominants & 0.93 & 0.89 \\
\hline
\end{tabular}
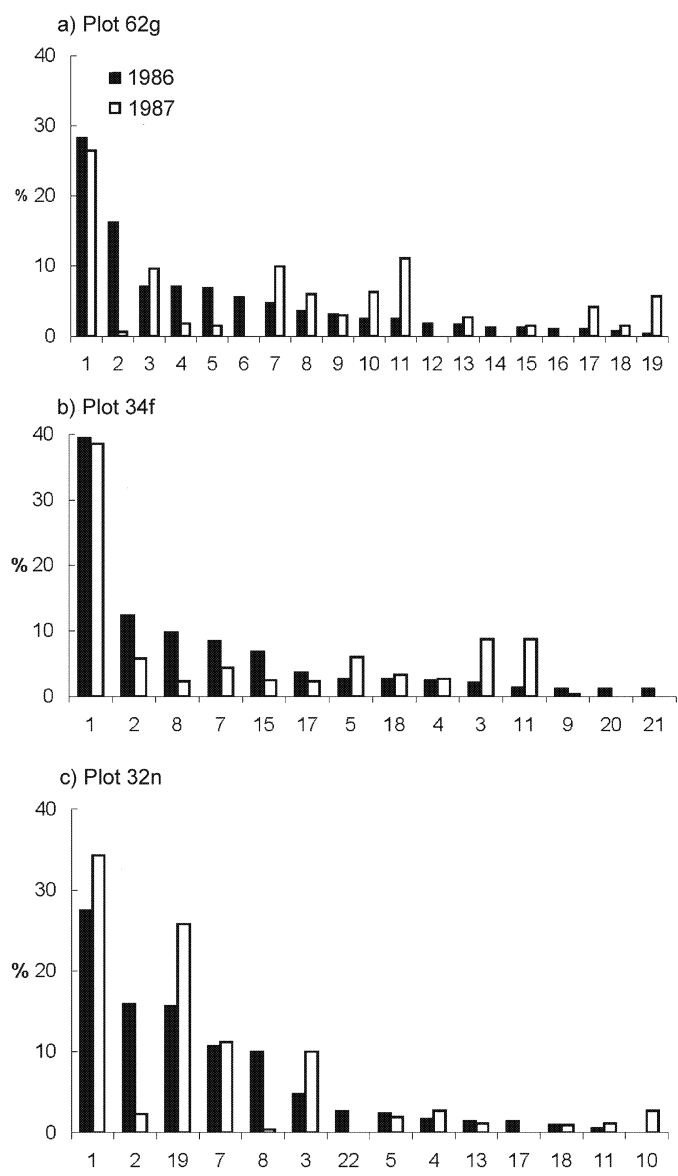

Fig. 1. Percentage of each species representing $\geq 1 \%$ of scuttle flies collected on the plots (62g, $34 f$ and $32 n)$ in 1986 and 1987. Numbers below the $x$ axis show the species: 1: Megaselia brevicostalis, 2: Megaselia verralli, 3: Metopina oligoneura, 4: Megaselia pleuralis, 5: Megaselia nigriceps, 6: Megaselia unicolor, 7: Megaselia pulicaria -complex, 8: Conicera similis, 9: Diplonevra funebris, 10: Megaselia giraudii -complex, 11: Megaselia manicata, 12: Borophaga subsultans, 13: Megaselia altifrons, 14: Megaselia diversa, 15: Megaselia xanthozona, 16: Megaselia hyalipennis, 17: Megaselia minor, 18: Megaselia pumila, 19: Megaselia scutellaris, 20: Megaselia involuta, 21: Triphleba trinervis, 22: Megaselia subnudipennis. 
Table 4. Characteristic species of pine plantations and their trophic group, percentage habitat fidelity $(F \%)$ and time (month) of peaks of male activity in the Biała Forest in 1986 and 1987. ? = unknown or probably known diet.

\begin{tabular}{llcll}
\hline Species & Trophic groups & Fidelity & I986 & 1987 \\
\hline Megaselia brevicostalis & Polysaprophagous & 99.8 & IV, VIII, IX & V, IX \\
Megaselia verralli & $?$ & 100 & VI, IX & IX \\
Megaselia scutellaris & Fungiphagous & 99.6 & VI, Iate IX & VII, IXIX \\
Metopina oligoneura & Polysaprophagous & 96.6 & VI, IX & V, VIII, IX \\
Conicera similis & Sapro/Fungiphagous & 100 & VI, VIII / IX & VI, VIIIIIX \\
Megaselia xanthozona & ? Saprophagous & 100 & IX & V, IX \\
Megaselia minor & Fungiphagous & 94.0 & VI, VIII / IX & VI, VIII, IX \\
Megaselia pumila & Fungiphagous & 89.3 & IX & IX \\
Diplonevra funebris & Necrophagous & 100 & V, late VIII & late VI, late VIII \\
Megaselia altifrons & ?Saprophagous & 100 & VI, VII & V, VIII \\
\hline
\end{tabular}

$100 \%$ ) fidelity to the study area (3 plots) were Megaselia brevicostalis, $M$. verralli, M. scutellaris, Metopina oligoneura, Conicera similis, $M$. xanthozona, M. minor, M. pumila, Diplonevrafunebris and $M$. altifrons. I consider these characteristic of the scuttle fly assemblages in pine plantations of the Biała Forest. Among them, those with known diet preferences are saprophagous/fungiphagous (Table 4).

\subsection{Phenology}

Both abundance and species richness of scuttle flies in most pine-plantation assemblages present on the three plots reached the highest peak at the end of August of the two study years (Figs 2-3). The characteristic species Megaselia brevicostalis, M. verralli, M. scutellaris, Metopina oligo-

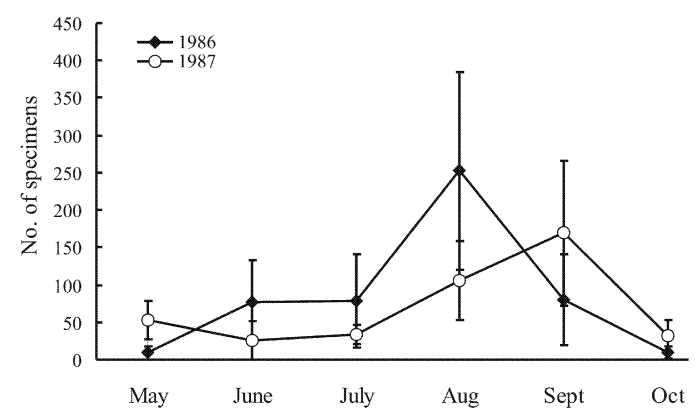

Fig. 2. Seasonal changes in abundance of adult scuttle flies caught by yellow pans in 1986 and 1987. The means and standard deviations of the figure are calculated from the means of the three plots $(62 g, 34 f$ and $32 n)$. neura, Conicera similis, $M$. xanthozona, M. minor, Diplonevra funebris and M. altifrons are multivoltine, displaying spring (May-June) and late summer/autumn (August-September) activity (Table 4). Though only observed in September, Megaselia pumila is also considered a multivoltine dominant of pine plantations (Durska 2006).

\section{Discussion}

The Biała Forest pine plantations appear to have a less rich scuttle fly fauna than Poland's Białowieża Primeval Forest $(s=75)$ or the Tuchola Forest $(s=77)$ (Durska 2006). However, all the assemblages present in pine plantations on the moist pine forest habitats of the Polish Lowland may in fact be markedly richer in scuttle fly speci-

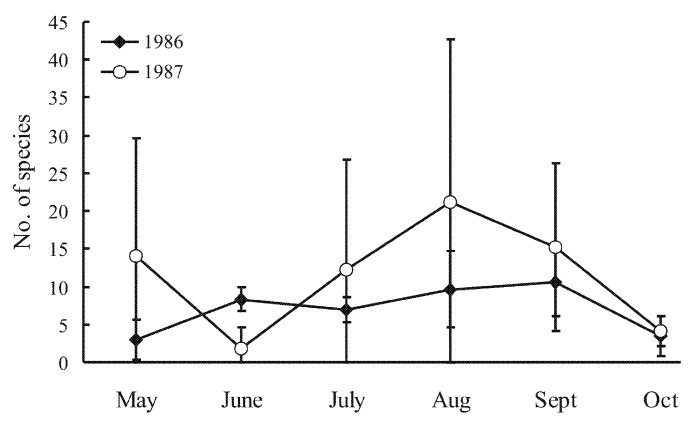

Fig. 3. Seasonal changes in number of species of adult scuttle flies caught by yellow pans in 1986 and 1987. The means and standard deviations of the figure are calculated from the means of the three plots $(62 g, 34 f$ and $32 n)$. 
es, since indentification of many Megaselia males (let alone females) proves problematical.

When comparing the species diversity of the scuttle fly assemblages from plots in pine plantations of three forest areas on the Polish Lowland (almost the same age, at the same time and using the same method), I noted the highest diversity for the Białowieża Primeval Forest (1986: $H^{\prime}=$ $\left.3.95,1987: H^{\prime}=3.86\right)$, and the lowest values for the Tuchola Forest $\left(1986: H^{\prime}=3.05,1987: H^{\prime}=\right.$ 2.78). The latter one is a managed forest where the situation in 1987 was affected by the extremely marked dominance of the polyphagous Megaselia pulicaria - complex, probably as a result of chemicals being employed against Neodiprion sertifer in 1986 (Durska 2006). The structure of the scuttle fly assemblages is thus seen to be markedly susceptible to quantitative environmental differences (Goos 1975; Durska 2006). In the Biała Forest, the scuttle fly assemblages of pine plantations were characterised by higher values for the diversity and evenness indices $\left(H^{\prime}=3.64\right.$ and $\left.J^{\prime}=0.92\right)$ than those of oldgrowth stands $\left(H^{\prime}=3.47, J^{\prime}=0.79\right)$. Furthermore, the same three open-area species $(M$. brevicostalis, $M$. verralli and Metopina oligoneura) that show the highest fidelity to the pine plantations of the Biała Forest, are also dominants and characteristic species of pine plantations in the Białowieża Primeval Forest and Tuchola Forest (Durska 2006).

Currently, little is known about the effectiveness of collecting methods for phorid flies. Brown \& Feener (1995) stated that Malaise traps are distinctly superior to pan traps in Southern Hemisphere studies. My use here of the yellow pan method reconfirms the results of previous work showing that Megaselia species make an extremely major contribution to assemblages of Phoridae (Disney 1994, Durska 1996, 2001a, 2006). Studies from Thunes et al. (2004), using a motorised canopy fogger, also identified Megaselia as the best-represented genus, accounting for over $80 \%$ of individuals collected. During four days of the experiment, only 91 individuals of Phoridae were noticed. Among sixteen determined species, five species were present in the assemblages of pine plantations in the Biała Forest. In turn, individuals of Megaselia spp. caught using Malaise traps in a wildfire site in dry pine fo- rest at Tyresta near Stockholm in August 1999, or else obtained using ground eclectors located in the chestnut belt following a wildfire in the Swiss Alps, again accounted for over $90 \%$ of all Phoridae sampled (Prescher et al. 2002; Durska unpubl.).

Overall, two of the dominants in my study of the scuttle fly assemblages on each pine-plantation plot (i.e. the pyrophilous Megaselia verralli and the polysaprophagous $M$. brevicostalis) are also dominants in heterogeneous habitats afflicted by wildfires, as in the aforementioned chestnut-belt of the Swiss Alps and the hemiboreal forests of Tyresta (Prescher et al. 2002; Durska unpubl.). I also found these same two species to be the dominants in the Piska Forest (Poland), in the wake of a windthrow incident that took place in July 2002 (Durska et al. in prep.).

The work I recount here further points to an overall tendency for both the dominants (species of relative abundance $\geq 1 \%$ ) and the characteristic species on all the pine-plantation plots to be good colonizers, tolerant of abiotic stress, and mainly generalists with multivoltine life cycle. Prescher (1992) and Buck (1997) observed the prevalence of the first dominant (Megaselia brevicostalis) also on each of the plots on open sites. It is characteristic for scuttle fly assemblages to present two peaks of abundance (a lower one in the spring and a higher one in early autumn), the same holding true for plantations in the moist pine forest habitat of the Białowieża Primeval Forest and Tuchola Forest. The autumn rise and fall in abundances of Megaselia species is probably most connected with the abundance of fungi (Disney 1994, Durska 1996, 2001a, 2006). Many scuttle fly species are known to be very sensitive to changes in their habitat, specially to climatic conditions (Folgarait et al. 2007). During dry years, $M$. brevicostalis reaches its abundance peak much earlier than in years when humidity is typical (Disney et al. 1981).

In the present study I have shown that the assemblages of Phoridae present in Biała Forest pine plantations are markedly different from those of its older pine stands. I attribute this difference to the increasing shade cast as young trees grow, and to the consequent replacement of photophilous species of open areas by forest-dwellers better adapted to the new conditions. 
My earlier work documented dramatic declines in the abundance of the early colonizers with increasing shade (Durska 1996, 2001a, 2002, 2006). The availability of light can have a major impact on diversity. In general assemblages are first dominated by generalists of good dispersal ability that are 'pressed for time'. Their greater tolerance of abiotic stress is associated with search times that are more limited, ensuring that they "have to accept suboptimal choices" (Prinzing 2003; Fernandez \& Costas 2004).

Taken together, the data I obtained during this and my previous studies suggest coherence amongst Phoridae and the development processes their assemblages pass through as moist pine forests in the Polish Lowland undergo secondary succession (Durska 1996, 2001a, 2006, unpubl.). Morover, the same reaction (characterised by the same group of dominant species and rather high species diversity) to disturbances (wildfire) of the open-area scuttle fly species has been obtained by Prescher et al. (2002). A parallel response to different disturbances (clear-cutting, grazing and burning) has also been found for spider and carabid fauna (Gibson et al. 1992; Zulka et al. 1997; Moretti et al. 2002; Fernandez \& Costas 2004; Huber \& Baumgarten 2005). The high species diversity present on each plot that has gone through forest clearance and/or a wildfire reflects the attendant habitat heterogeneity, and suggests a resilient response of scuttle fly assemblages to environmental stress. Resilience may be an indicator of stability, Manson et al. (2007) taking the term to mean "speed of recovery of community composition after perturbation". The scuttle fly assemblage of a small patch opened up by disturbance differs in its composition in direct association with how often such disturbances take place, in the manner discribed by the so-called "intermediate disturbance hypothesis" (IDH). This hypothesis could thus be tested using this group of flies (Roxburgh et al. 2004; Death \& Zimmermann 2005). Accordingly, it is possible to use Phoridae, as a group of very high ecological diversity, in monitoring of changes in terrestrial habitats following disturbances, or as other indicators within different ecological levels of organization (Durska 1996, 2001a, 2006, Prescher et al.2002). Further investigations of these possibilities remain necessary.
Acknowledgements. My work on Phoridae has benefited from SYNTHESYS support made available by the European Community - Research Infrastructure Action under the FP6 Structuring the European Area Programme ATTAF 543 and SE-TAF 1833. I would like to thank James Richards for English revision. For critical review of the manuscript and many valuable suggestions the author wishes to thank two anonymous referees for their helpful comments. I am also grateful to Krzysztof Gagla, M. Sc., for his invaluable assistance with the segregation of the material.

\section{References}

Bańkowska, R. \& Garbarczyk, H. 1982: Charakterystyka terenów badań oraz metod zbierania i opracowywania materiałów. In: Zoocenologiczne podstawy kształtowania środowiska przyrodniczego osiedla mieszkaniowego Białołęka Dworska w Warszawie. Part I. Skład gatunkowy i struktura fauny terenu projektowanego osiedla mieszkaniowego. - Fragmenta. Faunistica 26 (1981): 17-26.

Brown, B. V. \& Feener, Jr. D. H. 1995: Efficiency of two mass sampling methods for sampling phorid flies (Diptera: Phoridae) in a tropical biodiversity survey. - Contributions in Science 459: 1-8.

Buck, M. 1997: Untersuchungen zur ökologischen Einnischung saprophager Dipteren unter besonderer Berücksichtigung der Phoridae und Sphaeroceridae (Brachycera/Cyclorrhapha). Ph.D. thesis, Ulm University, Germany.

Death, R. G. \& Zimmermann, E. M. 2005: Interaction between disturbance and primary productivity in determining stream invertebrate diversity. - Oikos 111: $392-402$.

Disney, R. H. L. 1991: Family Phoridae. - In: Soós, A. \& Papp, L. (eds), Catalogue of Palaearctic Diptera. Volume 7 (Dolichopodidae-Platypezidae): 143-204. Akademiai Kiado, Budapeszt.

Disney, R. H. L. 1994: Scuttle flies: The Phoridae. Chapman \& Hall, London. 467 pp.

Disney, R. H. L. 2004: Species preferences for white versus yellow water traps for scuttle flies (Dipt, Phoridae). - Entomologist's Monthly Magazine 140: 31 35.

Disney, R. H. L., Coluson, J. C. \& Butterfield, J. 1981: A survey of the scuttle flies (Diptera: Phoridae) of upland habitats in Northern England. - Naturalist, Hull 106: 53-66.

Disney, R. H. L. \& Durska, E. 2008: Conservation evaluation and the choice of faunal taxa to sample. - Biodiversity and Conservation 17: 449-451.

Durska, E. 1996: The species composition and structure of scuttle fly communities (Diptera: Phoridae) in mature tree stands in pine forests at different stages of habitat degradation. - Fragmenta Faunistica 39: 267-285.

Durska, E. 2001a: Secondary succession of scuttle fly (Diptera: Phoridae) communities in moist pine forest in Białowieża Forest. — Fragmenta Faunistica 44: 81 130. 
Durska, E.2001b: Zadrowate (Diptera: Phoridae). - In: Gutowski, J. M. \& Jaroszewicz, B. (eds), Catalogue of the fauna of Białowieża Primeval Forest: 286-289. IBL, Warszawa.

Durska, E. 2002: The phenology of dominant scuttle-fly (Diptera: Phoridae) species in the Białowieża Forest. - Entomologica Fennica 13: 123-127.

Durska, E. 2003: The phenology of Triphleba Rondani species (Diptera: Phoridae) in moist pine forests in the Białowieża Forest. — Entomologica Fennica 14: 177 182.

Durska, E. 2006: Diversity of the scuttle fly (Diptera: Phoridae) communities in the plantations of moist pine forests of the Białowieża Primeval Forest and the Tuchola Forest (Poland). - Biodiversity and Conservation 15: 385-393.

Fernández Fernández, M. M. \& Salgado Costas, J. M. 2004: Recolonization of burnt pine forest (Pinus pinaster) by Carabidae (Coleoptera). - European Journal of Soil Biology 40: 47-53.

Folgarait, P. J., Patrock, R. J. W. \& Gilbert, L. E. 2007: The influence of ambient conditions and space on the phonological patterns of a Solenopsis phorid guild in an arid environment. - Biological Control 42: 262-273.

Gibson, C. W. D., Hambler, C. \& Brown V. K. 1992: Changes in spider (Araneae) assemblages in relation to succession and grazing management. - Journal of Applied Ecology 29: 132-142.

Goos, M. 1975: Influence of aphicides used in sugar-beet plantations on arthropods. IV. Studies on the flying insects captured in yellow receptacles. - Polskie Pismo Entomologiczne Bulletin entomologique de Pologne, Wrocław 45: 423-444. [In Polish, with English summary].

Horn, H. S. 1966: Measurement of „overlap” in comparative ecological studies. - American Naturalist 100: $419-424$.

Huber, Ch. \& Baumgarten, M. 2005: Early effects of forest regeneration with selective and small scale clear-cutting on ground beetles (Coleoptera, Carabidae) in a Norway spruce stand in Southern Bavaria (Höglwald). - Biodiversity and Conservation 14: 1989-2007.

Lunau, K., Hofmann, N. \& Valentin, S. 2005: Response of the Hoverfly species Eristalis tenax towards floral dot guides with colour transition from red to yellow (Diptera: Syrphidae). - Entomologica Generalis 27(3/4): 249-256.

Magurran, A. E. 1988: Ecological Diversity and its Measurement. Princeton University Press, New Jersey.

Manson, N. W. H., Wilson, J. B. \& Steel, J. B. 2007: Are alternative stable states more likely in high stress environments? Logic and available evidence do not support Didham et al. 2005. — Oikos 116: 353-357.

Matuszkiewicz, J., Degórski, M. \& Kozłowska, A. 1993: Description of the plant association structure and soils of pine forest stands situated in five regions of Poland. In: Species composition and structure of pine forests fauna in Poland. Part I. - Fragmenta Faunistica 36: 13-36.
Moore, P. D. 2005: Roots of stability. — Nature 437: 959 961.

Moretti, M., Conedera, M., Duelli, P. \& Edwards, P.J. 2002: The effects of wildfire on ground-active spiders in deciduous forests on the Swiss southern slope of the Alps. - Journal of Applied Ecology 39: 321-336.

Östman, Ö., Kneitel, J. M. \& Chase, J. M. 2006: Disturbance alters habitat isolation's effect on biodiversity in aquatic microcosms. - Oikos 114: 360-366.

Prescher, S. 1992: Ökologie und Biologie der Diptera, insbesondere der Brachycera, eines klärschlammgedüngten Ackerbodens. Ph.D. thesis, Braunschweig University, Germany.

Prescher, S., Moretti, M. \& Duelli, P. 2002: Scuttle flies (Diptera, Phoridae) in Castanea sativa forests in the southern Alps (Ticino, Switzerland), with thirteen species new to Switzerland. Mitteilungen der Schweizerischen Entomologischen Gesellschaft. - Bulletin de la Société Entomologique Suisse 75: 289-298.

Prinzing, A. 2003: Are generalists pressed for time? An interspecific test of the the time-limited dispersal model. — Ecology 84(7): 1744-1755.

Roxburgh, S. H., Shea, K. \& Wilson, J. B. 2004: The intermediate disturbance hypothesis: patch dynamics and mechanisms of species coexistence. - Ecology 85(2): 359-374.

Sørensen, T. 1948: A method of establishing groups of equal amplitude in plant sociology based on similarity of species content and its application to analyses of the vegetation on Danish commons. - Biologiske Skrifter 5: 1-34.

Thunes, K. H., Skartveit, J., Gjerde, I., Starý, J., Solhřy, T., Fjellberg, A., Kobro, S., Nakahara, S., zur Strassen, R., Vierbergen, G., Szadziewski, R., Hagan, D. V., Grogan Jr., W.L., Jonassen, T., Aakra, K., Anonby, J., Greve, L., Aukema, B., Heller, K., Michelsen, V., Haenni, J.-P., Emeljanov, A. F., Douwes, P., Berggren, K., Franzen, J., Disney, R. H.L., Prescher, S., Johanson, K. A., Mamaev, B., Podenas, S., Andersen, S., Gaimari, S.D., Nartshuk, E., Sřli, G. E. E., Papp, L., Midtgaard, F., Andersen, A., von Tschirnhaus, M., Bächli, G., Olsen, K. M., Olsvik, H., Földvári, M., Raastad, J. E., Hansen, L. O. \& Djursvoll, P. 2004: The arthropod community of Scots pine (Pinus silvestris L.) canopies in Norway. - Entomologica Fennica 15: 65-90.

Tanner, E. V. J. \& Bellingham, P. J. 2006: Less diverse forest is more resistant to hurricane disturbance: evidence from montane rain forests in Jamaica. - Ecology 94: 1003-1010.

Tscharntke, T.\& Brandl, R. 2004: Plant-insect interactions in fragmented landscapes. - Annual Review of Entomology 49: 405-430.

Zulka, K.P., Milasowszky, N. \& Lethmayer, Ch. 1997: Spider biodiversity potential of an ungrazed and grazed inland salt meadow in the National Park, ,Neusiedler See-Seewinkel" (Austria): implications for management (Arachnida: Araneae). - Biodiversity and Conservation 6: 75-88. 